\title{
Vegetational and Pedological Characterization of a Grazing Land in Central Sardinia and First Proposals for Improvement and Rational Use
}

\author{
Lorenzo Salis ${ }^{1 *}$, Rita Puddu ${ }^{2}$, Stefania Fanni², Mirella Vargiu ${ }^{2}$ \\ ${ }^{1}$ Dipartimento per la Ricerca nelle Produzioni Animali, AGRIS \\ Bonassai S.S. 291 km. 18.6, 07040 Olmedo (SS), Italy \\ ${ }^{2}$ Dipartimento per la Ricerca nelle Produzioni Vegetali, AGRIS \\ Viale Trieste 111, 09123 Cagliari, Italy
}

Received: 10 July 2007. Accepted: 10 October 2007.

\begin{abstract}
Sardinia's grazing lands are characterized by a wide variety of vegetable species whose presence and frequency are determined by environmental and anthropic factors; they are widespread throughout the land and involve pedological types with quite variable physical, chemical and hydrological characteristics. A floristic and agronomic study of grazing lands is thus fundamental in putting them to best use and protecting resources. A pedological and vegetational study was carried out on a hilly grazing land in central Sardinia in the Marghine-Planargia region, characterized by frequent phenomena of waterlogging. The floristic analysis revealed three well-defined vegetational facies in connection with the same number of situations defined by pedological properties. Facies A presents the highest grazing value (50.6). Facies B and, in particular, facies C, connected with grazing areas affected by waterlogging caused by peculiar soil physical and structural features, have lower grazing values (39.1 and 38.6 respectively), but still high owing to the presence of species having good pasture value. A detailed analysis of hydrodynamic characteristics revealed the moisture limits to be considered for the proper use of the soil as pasture land. In such areas, simple works to favour the outflow of excess water would lengthen the grazing period, with the consequent increase in their agronomic value.
\end{abstract}

Key-words: soil characterization, waterlogging, floristic analysis, grazing value.

\section{Introduction}

In Sardinia, natural pasture lands represent the main source of feed for animals and, with an extension of over one million hectares, occupy approximately $87 \%$ of the island's total forage surface (ISTAT 2005). Sardinian pastures have a high level of biodiversity; the presence and frequency of species depend on the interaction of different factors which are mainly of a climatic (Arrigoni, 1968), pedological (Guckert and Bonishot, 1984) and antropic (Camarda, 1987) nature.

The island's Mediterranean climate is subdivided into many microclimates with different seasonal and annual characteristics depending on numerous factors, including altitude, orography and exposure. As concerns plant distribution, the most significant limiting elements are low winter temperatures and summer drought, which determine vegetational periodicity (Arrigoni, 2006).

From the pedological standpoint, the high degree of heterogeneity of Sardinian soils (Aru et al., 1991) has a great influence on the composition of the phytocoenosis of pasture lands in consideration of nutritional requirements and $\mathrm{pH}$ which distinguish the different vegetable species. Especially important are water retention capacity and drainage of excess water in the soil, on which depend the availability of water for plants and the presence of more or less lengthy periods of waterlogging; moreover, in surrounding areas with limited variations in altitude, the main discriminating factor for spontaneous flora is the availability of water (Guckert and Bonishot, 1984).

\footnotetext{
* Corresponding Author: Tel.: +39 079 387310; Fax: +39 079 389450. E-mail address: foraggisassari@tiscali.it
} 
The anthropic effect on the floristic equilibrium of natural pasture lands depends mostly on the introduction of foreign species, the use of invasive agronomic techniques, such as the use of fire to eliminate vegetational residues, and the use of pasture with overgrazing; most of all it is the latter factor, widespread in Sardinia's marginal areas, that leads to a decrease in the quality of grazing lands caused by the success of species with little or no pabular value (Salis et al., 2005). Among the aspects of soil deterioration connected with overgrazing in Sardinia, as in many other Mediterranean areas, the most visible effect is the compacting of the surface layer, especially in the case of fine-textured soils, which leads to a sharp decline in porosity and a consequent variation in the entire soil hydrological cycle (Aru et al., 1998). In the steeper areas this leads to an increase in surface runoff and the risk of erosion, while in flatter areas there is a reduced capacity of water retention, an increase in resistance to penetration and a noteworthy decrease in root growth (Vacca et al., 2003).

The characterization of a pasture from the botanic and agronomic viewpoints represents an indispensable element in determining its best use, conservation and renewal of its resources (Roggero et al., 2002).

The purpose of this study is to vegetationally and pedologically characterize a hilly pasture land in central Sardinia with continuous sheep grazing and partially subject to long periods of waterlogging so as to propose useful suggestions for its management and the preservation of the quality of its soil and plant resources.

\subsection{Geological and climatic profile}

The study area, which is a pasture of approximately 10 hectares on lands belonging to the municipality of Borore, is on Sheet 498140 of the Regional Technical Map, in the "MarghinePlanargia" region at an altitude of 390 metres above sea level (Fig. 1). The geological bedrock is composed solely of basaltic lava of the volcanic-alkaline cycle which involved the Marghine region during a tectonic phase of distension in the Plio-Pleistocene (Carmignani, 2001). Morphologically, the site is located at the centre of a hollow with weak slopes varying from top to bottom from $6 \%$ to $0.5 \%$.

On the basis of the Thornthwaite and Math-

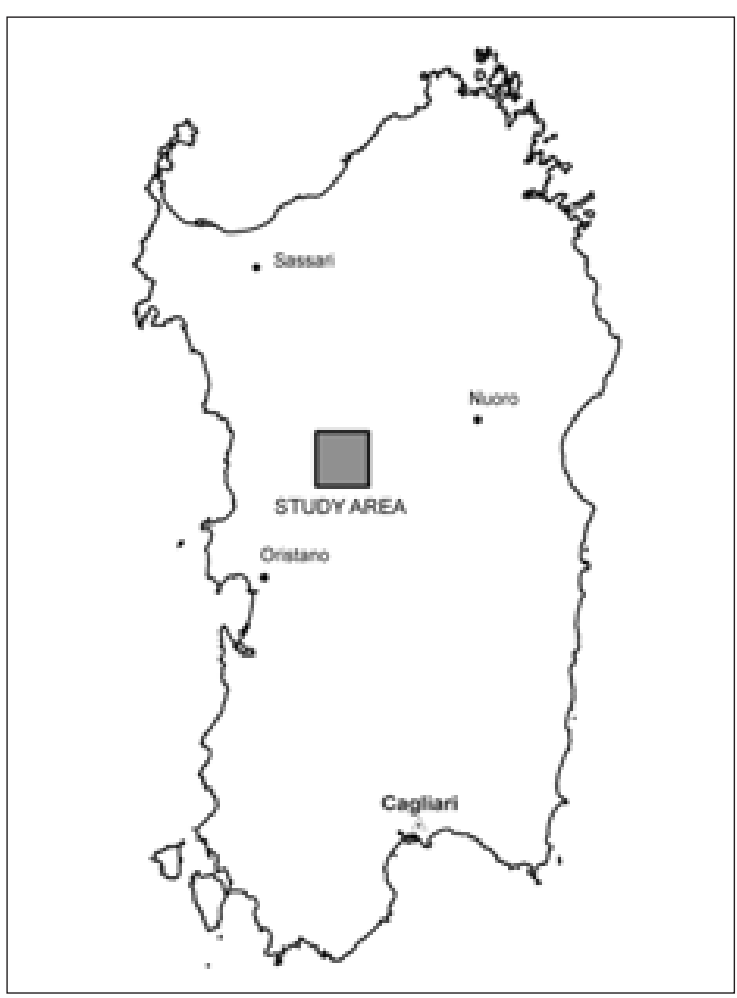

Figure 1. Geographic view of the study area.

er parameters, the climate in the area is classified as mesothermal-humid (Arrigoni, 2006), with average annual rainfall above $1000 \mathrm{~mm}$ and temperatures varying from $4{ }^{\circ} \mathrm{C}$ (mean January minimum) to $32{ }^{\circ} \mathrm{C}$ (mean August maximum).

\section{Materials and methods}

The study was carried out in the spring of 2005, following a preliminary investigation in the autumn of 2004 which revealed a high level of heterogeneity in the study area both as concerns vegetational characteristics and the presence of the persistence of surface waterlogging. In the light of these findings, the grazing land was divided into three fairly homogeneous areas (A, $\mathrm{B}$ and C) of similar extension (Fig. 2). The areas were characterized from the pedological and hydrological standpoints by performing the following:

- the aperture and description of three pedological profiles with sampling of the diagnostic horizons;

- chemical and physical analyses of each sampled horizon and evaluation of the main hy- 


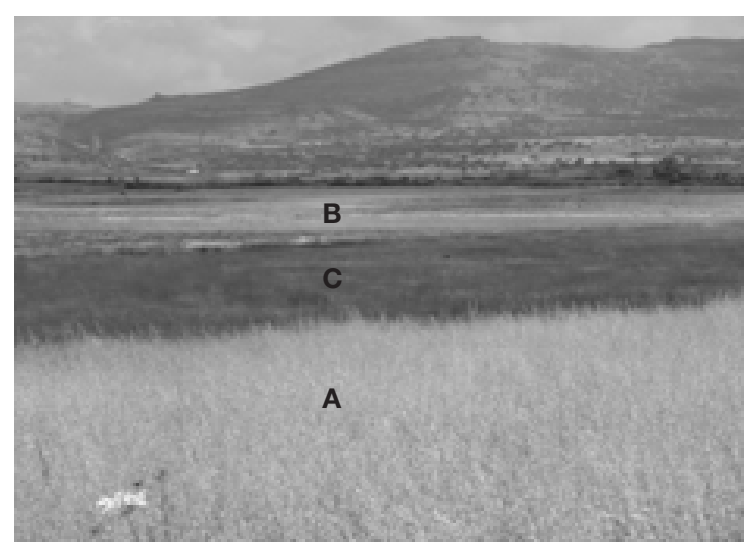

Figure 2. Vegetational facies of Borore pasture in the spring period: area $\mathrm{A}$ in the foreground, $\mathrm{C}$ and $\mathrm{B}$ in the centre and in the background respectively.

drological parameters $(\mathrm{pF}$ at field capacity and at wilting point);

- limited only to the surface horizons of areas $\mathrm{B}$ and $\mathrm{C}$, the Atterberg limits, that is, water content at the limit of liquidity $\left(\mathrm{W}_{\mathrm{L}}\right)$ and at the limit of plasticity $\left(\mathrm{W}_{\mathrm{P}}\right)$. These parameters, commonly employed in soil mechanics testing, were used to determine the index of relative consistency with the formula $\mathrm{Ic}=\mathrm{W}_{\mathrm{L}}$ - $\mathrm{Wc} / \mathrm{W}_{\mathrm{L}}-\mathrm{W}_{\mathrm{P}}$ where $\mathrm{Wc}$ indicates soil water content in the natural state (Casadio and Elmi, 1995).

The soil moisture $(\mathrm{Wc})$ trend was monitored every fifteen days during the spring months by taking six soil samples per area. The samples were then oven-dried at $105{ }^{\circ} \mathrm{C}$ (gravimetric method), so as to verify water availability and, by comparison with the other hydrological parameters measured, any excess water there may have been during the vegetative regrowth of the pasture.

The description of the soils was drawn up following FAO guidelines (FAO, 1977); soil classification was determined on the basis of USDA Soil Taxonomy (USDA Soil Survey Staff, 2006). Laboratory analyses were performed following the "Official methods for the chemical and physical analyses of soil" of the Italian Ministry for Agricultural and Forestry Policies (Violante, 2000; Pagliai, 2001); the Atterberg limits were established according to 10014-ASTM 4318 standards of the Italian Research Council.

For the study of the prevalent phytocoenoses, the linear analysis method (Daget and
Poissonet, 1969) was employed using four-metre transepts and noting vegetation at twenty points along each one to calculate the presence specific contribution [CSP]. For each area of the study, 12 lines of flora for a total of 36 lines were laid out in the spring; in order to perform the vegetation survey of the area, which was usually open to grazing, it was enclosed to keep the animals out in the previous autumn and winter. The data thus collected were subjected to a hierarchical Cluster Analysis with the Ward method for calculation of similarities of groups. The lines were analysed all together for statistical verification of the presence of different vegetational facies in the three areas under consideration. Data on CSP of the species were used in calculating the grazing value of the pasture in the three areas following the Daget and Poissonet (1969) method expressed by the formula: $\mathrm{VP}=0,2 \times \sum \mathrm{CSP}_{\mathrm{i}} \times \mathrm{Is}_{\mathrm{i}}$, where $\mathrm{Is}_{\mathrm{i}}$ is the specific index of species $i$. The indices used are those calculated for the Mediterranean area by Roggero (Roggero et al., 2002) which are available at the Internetsite of the Facoltà di Agraria of Ancona, Italy < URL: http://ingweb.unian.it/ Agraria/>.

\section{Results and discussion}

The meteorological trend from the summer of 2004 to the spring of 2005 differed slightly from the mean thirty-year values. Annual rainfall was $790 \mathrm{~mm}$, and only in the months of August, October, April and May was it above average. The minimum and maximum temperatures were constantly below average (with the exception of August 2004) with accentuated differences between the highest temperatures, which were above $7{ }^{\circ} \mathrm{C}$ in May. Figure 3 shows the climat-

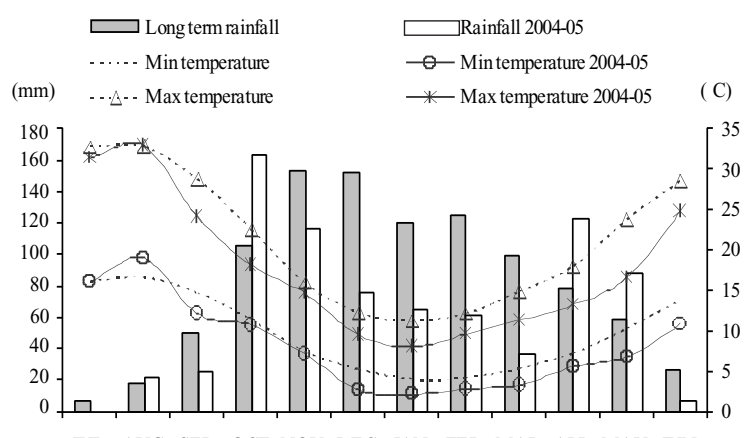

JUL AUG SEP OCT NOV DEC JAN FEB MAR APR MAY JUN

Figure 3. Long term and annual temperature and rainfall. 
Salis L., Puddu R., Fanni S., Vargiu M.

Table 1. Specific contribution (SC) percentage of the single botanic species in the vegetational facies of the study area.

\begin{tabular}{|c|c|c|c|c|c|}
\hline Facies A & $\begin{array}{l}\mathrm{SC} \\
(\%)\end{array}$ & Facies B & $\begin{array}{l}\text { SC } \\
(\%)\end{array}$ & Facies $\mathrm{C}$ & $\begin{array}{l}\mathrm{SC} \\
(\%)\end{array}$ \\
\hline T. subterraneum ssp. sub L. & 11.5 & T. subterraneum ssp. sub. L. & 11.3 & Schoenus nigricans L. & 9.9 \\
\hline Trifolium nigrescens Viv. & 11.0 & Bromus hordeaceus L. & 10.2 & Medicago minima Bartal. & 9.8 \\
\hline Bromus madritensis L. & 10.1 & Hordeum marinum Huds. & 10.1 & Poa аппиа $\mathrm{L}$. & 7.6 \\
\hline Calepina irregularis Thell. & 6.1 & Gaudinia fragilis L. & 8.2 & Lolium perenne L. & 7.6 \\
\hline Avena sterilis L. & 5.3 & Medicago minima Bartal. & 7.8 & Anthoxanthum aristatum L. & 7.5 \\
\hline Hordeum leporinum Link. & 4.5 & Hordeum hystrix Roth & 7.5 & Cynosurus cristatus L. & 7.3 \\
\hline Plantago lanceolata $\mathrm{L}$. & 4.4 & Vulpia geniculata (L.) Link. & 5.1 & Gaudinia fragilis L. & 5.9 \\
\hline Sheradia arvensis L. & 4.0 & Sheradia arvensis L. & 4.0 & T yanninicum Katzn e Morley. & 5.6 \\
\hline Lolium perenne L. & 4.0 & Ranunculus sardous Crantz & 3.6 & Alopecurus myosuroides Hud. & 4.8 \\
\hline Bromus hordeaceus L. & 3.9 & Bromus madritensis L. & 3.4 & Bromus hordeaceus L. & 3.9 \\
\hline Anthoxanthum aristatum L. & 3.5 & Trifolium nigrescens Viv. & 3.1 & Hordeum marinum Hudson. & 3.6 \\
\hline Cerastium glomeratum Thuill & 1. 3.4 & Phalaris coerulescens Desf. & 3.1 & Vulpia ligustica Link. & 2.8 \\
\hline Leontodon tuberosus L. & 3.1 & Anthoxanthum aristatum L. & 2.7 & Vulpia myuros (L.) Gmelin & 2.5 \\
\hline Medicago polymorpha $\mathrm{L}$. & 2.7 & Lolium perenne L. & 2.6 & Agropyron repens L. & 2.4 \\
\hline Scolymus hispanicus L. & 2.3 & Scolymus hispanicus L. & 2.4 & Leontodon tuberosus L. & 1.9 \\
\hline Cynosurus echinatus L. & 2.0 & Geranium molle L. & 1.7 & Vulpia geniculata (L.) Link. & 1.9 \\
\hline Anthemis arvensis L. & 1.8 & Lotus corniculatus L. & 1.2 & Ranunculus sardous Crantz & 1.9 \\
\hline Gaudinia fragilis L. & 1.6 & Leontodon tuberosus L. & 1.0 & Phalaris tuberosa L. & 1.7 \\
\hline Poa sp. L. & 1.4 & Elymus caput meduse L. & 1.0 & Lotus corniculatus L. & 1.4 \\
\hline Capsella bursa pastoris L. & 1.2 & & & Chondrilla Juncea L. & 1.4 \\
\hline Reichardia picroides L. Roth & 1.2 & & & Poa infirma H.B.K. & 1.3 \\
\hline Chondrilla Juncea L. & 1.1 & & & Juncus bufonius L. & 1.3 \\
\hline Vulpia geniculata (L.) Link. & 1.0 & & & Bromus madritensis L. & 1.2 \\
\hline
\end{tabular}

Table 2. Frequency (\%) of the main botanic families in the three vegetational facies.

\begin{tabular}{lccc}
\hline Families & Facies A & Facies B & Facies C \\
\hline Legumes & 28 & 26 & 18 \\
Grasses & 39 & 58 & 63 \\
Others & 33 & 16 & 19 \\
\hline
\end{tabular}

ic characteristics of the site compared to the meteorological trend of the year under investigation (data referring to the 1961-1990 thirty-year period at the nearby Macomer station).

\subsection{Vegetational characteristics}

The floristic analysis of the pasture revealed the presence of ninety different herbaceous species. The dendrogram derived from the cluster analysis showed the formation of three well-differentiated groups of lines of flora (a high value of the coefficient of fusion among the groups) in the three study areas, A, B and C (Fig. 4); to each group corresponds a vegetational facies as shown in table 1.

Facies A is characterized by the predominance of Trifolium subterraneum ssp. subterraneum, T. nigrescens and Bromus madritensis, which together represent about one third of the specific frequencies. The great amount of the clovers found, considered to be excellent feed (specific index of 5), lets that the grazing area relating to this facies has a higher grazing value (50.6) than the other two. On grouping the species by botanical families we can see that it is a balanced pasture, with legumes and grasses species representing $32 \%$ and $39 \%$ respectively of the overall frequencies (Tab. 2). Area A also differs sharply from the pedological viewpoint and for the absence of waterlogging, as will be described in greater detail below.

In facies B the most representative floristic elements are T. subterraneum ssp. subterraneum, Bromus hordeaceus and Hordeum marinum. The ratio between legumes and grasses species in the grazing land shifts clearly in favour of the latter ( $26 \%$ vs. $58 \%$ ); also to be noted is the presence of species such as Gaudinia fragilis and Ranunculus sardous characteristic of humid meadows with waterlogging. The agronomic value of this area is lower than that of area A, not only in terms of floristic composition, which determines a lower grazing value (39.1), but also in terms of shorter grazing periods owing to presence of waterlogging in the spring season as better specified later.

Finally, the facies $\mathrm{C}$ area, which is characterized by the highest soil moisture, as testified by the high frequency of species typical of hu- 


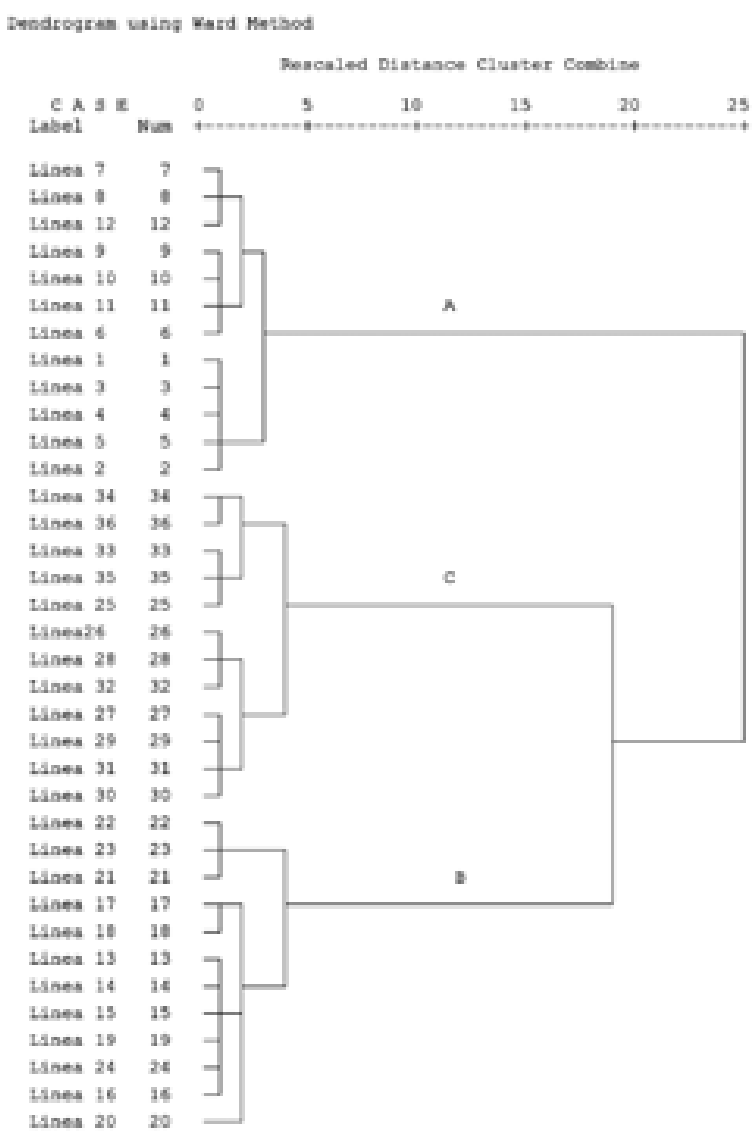

Figure 4. Dendrogram derived from the cluster analysis of the 36 floristic lines: A, B and C indicate vegetational facies of the three grazing areas studied. mid and peaty soil such as the Cyperacea Schoenus nigricans, or others that prefer cool areas and possess great resistance to stagnant water such as Poa annua and Cynosurus cristatus. Grasses species represent $63 \%$ while the frequency of legumes species goes down to $18 \%$, a confirmation of the poorer adaptation of the latter to excess humidity. In any case, the vegetational analysis shows a grazing value similar to that of area B (38.6), with the significant presence of species with high feed value such as T. subterraneum var. yanninicum and Lolium perenne which resist waterlogging.

\subsection{Soil characteristics}

Soil profiles were described along a transept with a directrix parallel to the vegetational profiles. The main pedogenetic factor is determined by the morphology of the site rather than by the parent material, which is constantly represented by alkaline basalts with different degrees of weathering and fracturing. In-the-field surveys and laboratory analyses showed that pedological homogeneity is found only for slopes of $<1 \%$ (areas B and C) where the soils, even at the taxonomic level, are totally different from those of the higher area (area A). The most important difference is the sharp increase in the clayey fraction in areas $\mathrm{B}$ and $\mathrm{C}$, both on the surface and in depth (Tab. 3). In particular, in

Table 3. Main pedological and agronomic parameters of the areas under examination.

\begin{tabular}{|c|c|c|c|c|c|c|c|c|c|c|c|c|}
\hline \multirow{2}{*}{\multicolumn{2}{|c|}{$\begin{array}{l}\text { Parameters } \\
\text { Altitude (metres above sea level) }\end{array}$}} & \multicolumn{3}{|c|}{ Area A } & \multicolumn{5}{|c|}{ Area B } & \multicolumn{3}{|c|}{ Area $\mathrm{C}$} \\
\hline & & \multicolumn{3}{|c|}{390.0} & \multicolumn{5}{|c|}{388.7} & \multicolumn{3}{|c|}{389.4} \\
\hline \multicolumn{2}{|l|}{ Slope $(\%)$} & \multicolumn{3}{|c|}{5.7} & \multicolumn{5}{|c|}{0.79} & \multicolumn{3}{|c|}{0.68} \\
\hline \multicolumn{2}{|c|}{ Depth of soil parent material $(\mathrm{cm})$} & \multicolumn{3}{|c|}{120} & \multicolumn{5}{|c|}{70} & \multicolumn{3}{|c|}{100} \\
\hline Diagnostic horizons & A1 & A2 & $\mathrm{Bw}$ & $\mathrm{Bt} / \mathrm{R}$ & A & Bw1 & Bw2 & $\mathrm{C}$ & A & Bw1 & Bw2 & $\mathrm{C} / \mathrm{R}$ \\
\hline Thickness $(\mathrm{cm})$ & 6 & 44 & 45 & $35>$ & 20 & 37 & 13 & $30>$ & 10 & 55 & 35 & $20>$ \\
\hline Sand $(\mathrm{g} / \mathrm{kg})$ & 307 & 257 & 352 & 406 & 413 & 112 & 93 & 341 & 262 & 97 & 145 & 367 \\
\hline Silt $(\mathrm{g} / \mathrm{kg})$ & 569 & 522 & 409 & 348 & 170 & 246 & 438 & 378 & 339 & 325 & 384 & 305 \\
\hline Clay $(\mathrm{g} / \mathrm{kg})$ & 124 & 221 & 239 & 246 & 417 & 642 & 469 & 281 & 399 & 578 & 471 & 328 \\
\hline Texture & FL & FL & $\mathrm{F}$ & $\mathrm{F}$ & A & A & $\mathrm{AL}$ & FA & A & A & A & FA \\
\hline $\mathrm{pH}$ in $\mathrm{H}_{2} \mathrm{O}$ & 6.1 & 6.8 & 7.0 & 7.0 & 6.4 & 7.0 & 8.7 & 8.7 & 6.8 & 7.9 & 8.2 & 7.6 \\
\hline Organic carbon $(\mathrm{g} / \mathrm{kg})$ & 61.2 & 12.5 & 8.1 & 6.4 & 37.2 & 11.7 & 4.0 & 3.0 & 43.1 & 12.0 & 6.1 & 3.1 \\
\hline Organic matter $(\mathrm{g} / \mathrm{kg})$ & 105 & 22 & 14 & 11 & 64 & 20 & 7 & 5 & 74 & 21 & 10 & 5 \\
\hline CEC (me/100g) & 33.8 & 21.9 & 19.8 & 19.4 & 35.2 & 43.7 & 22.2 & 26.3 & 44.5 & 36.8 & 33.7 & 26.2 \\
\hline $\begin{array}{l}\text { Assimilable phosphorus } \\
\text { (mg/Kg) } \\
\text { Exchangeable }\end{array}$ & 5.8 & 3.4 & 6.9 & 8.6 & 8.4 & 7.2 & 6.1 & 5.7 & 10.5 & 9.68 & 11.1 & 12.3 \\
\hline potassium $(\mathrm{mg} / \mathrm{Kg})$ & 232 & 10.5 & 7.34 & 10.4 & 46.6 & 31.7 & 49.1 & 42.2 & 39 & 40.4 & 61 & 60 \\
\hline Total nitrogen $(\mathrm{g} / \mathrm{kg})$ & 5.6 & 1.2 & 0.8 & 0.7 & 3.4 & 1.2 & 0.5 & 0.2 & 4.0 & 1.1 & 0.6 & 0.6 \\
\hline Field capacity ( $\mathrm{pF} 2.5)$ & 36.5 & 25.6 & 25.7 & 22.6 & 48.8 & 55.0 & 40.3 & 36.5 & 47.0 & 53.7 & 53.3 & 41.1 \\
\hline Wilting point ( $\mathrm{pF} 4.2)$ & 19.1 & 12.0 & 12.0 & 12.1 & 31.4 & 35.3 & 23.6 & 17.9 & 30.7 & 35.5 & 33.6 & 22.1 \\
\hline
\end{tabular}




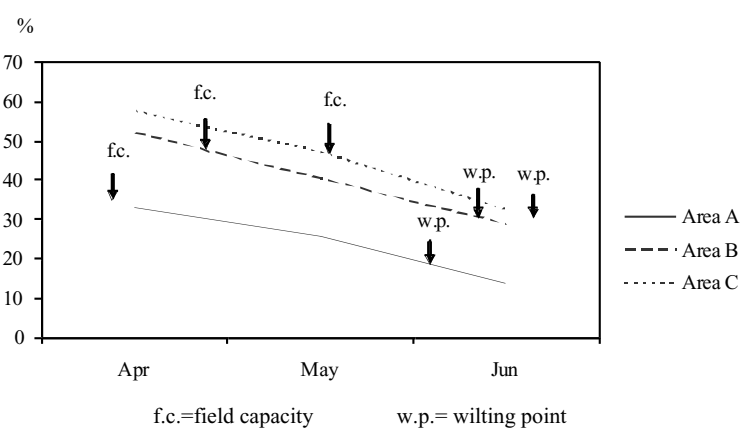

Figure 5. Variation in soil moisture (dry weight percentage) in the three areas examined in the spring 2005.

these areas the process of pedoturbation predominates; this is clearly shown by the fissures and typical superficial "gilgai" microreliefs indicative of the presence of clays with an expandable mineral clays. Thus, the high content of the fine component, together with the flat morphology, causes a strong reduction in drainage and the persistence of waterlogging up to the summer months. In Figure 5 we see the moisture trend monitored in the three areas during the spring. The curves, derived from the mean monthly datum, show water content, which is clearly lower in area A owing to its textural and morphological (slope $>5 \%$ ) features which are more favourable to drainage. istics:

In general, we find the following character-

1) area $\mathrm{A}$ is dominated by more developed soils and well-differentiated diagnostic horizons; according to Soil Taxonomy these soils are classified as the fine-loamy, mixed, thermic Inceptic Haploxeralfs.

The typical profile (Fig. 6) is given by the sequence $\mathrm{A}-\mathrm{Bw}-\mathrm{Bt} / \mathrm{R}$, where it is possible to find good textural homogeneity down to a depth of one metre (textures from silt-loam to loam). The dominant processes are the result of a slow translocation of the clay in depth and the beginning of an evolution of the cambic horizon to argillic horizon at approximately $100 \mathrm{~cm}$. Down to this depth, however, the soil profile denotes good overall permeability, favoured by the abundance of medium and large pores with a high degree of vertical continuity. In this area of the grazing land no waterlogging was found in spring; soil moisture values remained below those of field capacity and went below the wilting point at the beginning of June.

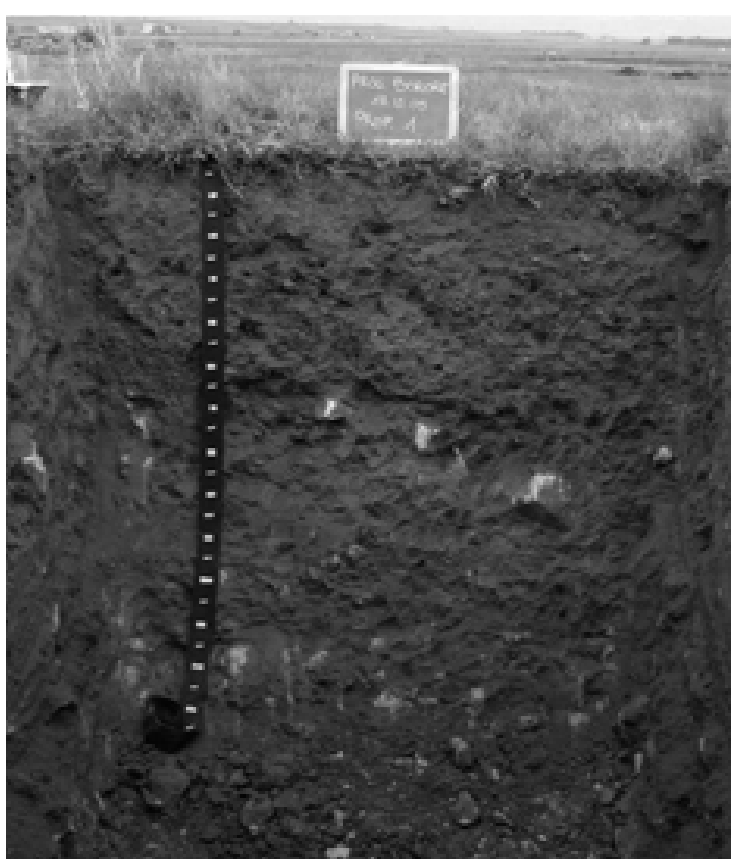

Figure 6. Soil profile representative of area A.

2) the soils in areas B and C present quite similar physical and chemical properties, which determine the same taxonomic family (fine, smectitic $^{1}$, thermic Xeric Epiaquerts). Between the profiles of the two areas there are no substantial differences, either in the sequence of horizons (profiles of the A-Bw-C$\mathrm{R}$ type), or morphology, if we exclude a slightly more depressed position of area $\mathrm{C}$ compared to area B, with a slope of $0.68 \%$ vs. $0.79 \%$ (Fig. 7). The peculiar characteristic of these soils is the presence of clays with an expandable reticule which causes seasonal phenomena of swelling and contraction with changes in humidity, the formation of deep cracks during the dry season and consequent incorporation and homogenization of the organic substance inside the profile. In both profiles, macroporosity, although quite abundant, is dominated by the finest size class (pore $\varnothing<0.5 \mathrm{~mm}$ ).

At the microscale level, however, a certain variability in hydrological behaviour was found, which is to say that the removal of gravitation-

\footnotetext{
${ }^{1}$ Attribution to the smectitic class is hypothesized on the basis of the nature of the substrate, but has not been confirmed by the necessary mineralogical analyses.
} 

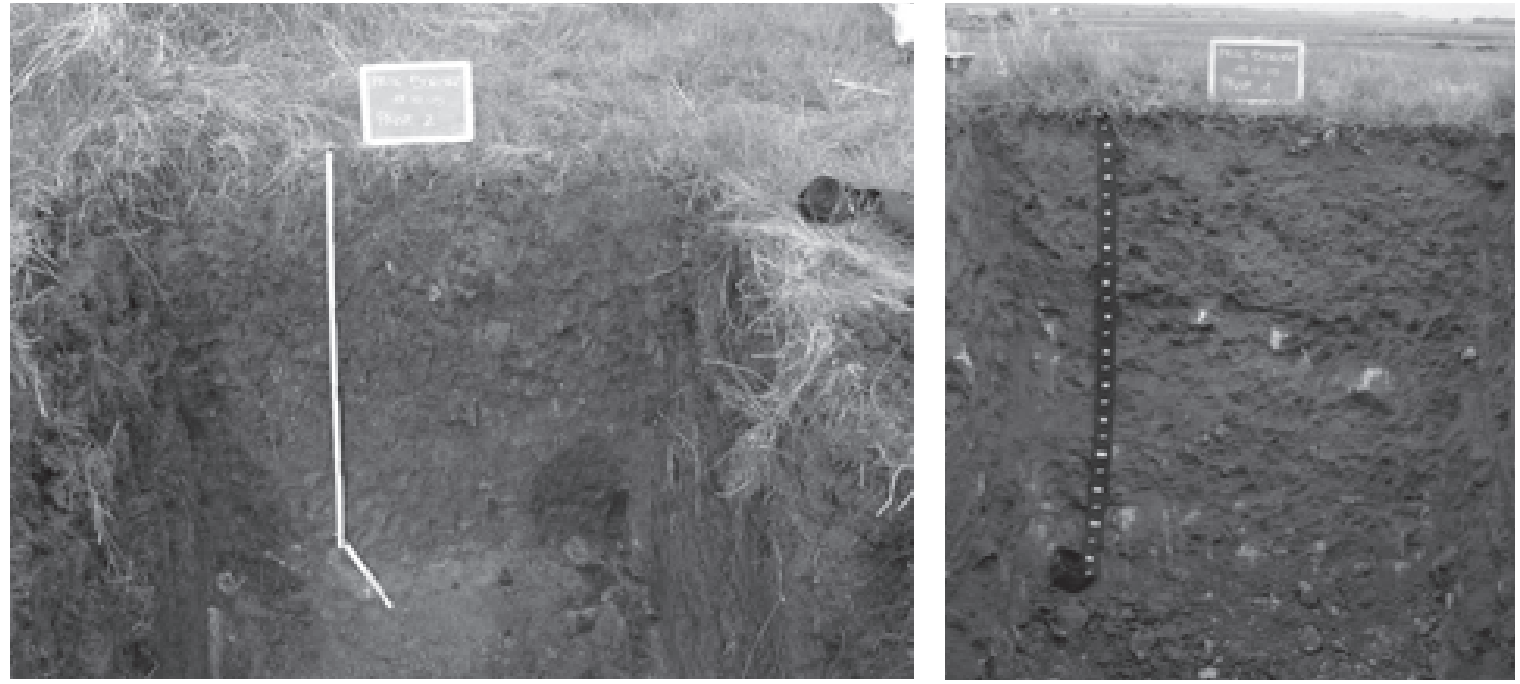

Figure 7. Soil profiles representative of area C (left) and area B.

al water in area $\mathrm{C}$ was more difficult, at least partly due to two important characteristics found in the relative soil profiles:

a) the sharp increase in clay after the first 10 $\mathrm{cm}$ (from $40 \%$ to $58 \%$ ) and, more specifically, a higher content of the "silt + clay" fine component $(74 \%$ in area $\mathrm{C}$ vs. $59 \%$ in area B) in the first horizon;

b) a greater thickness of the horizons with a clayey texture $(100 \mathrm{~cm}$ in the area $\mathrm{C}$ profile vs. $57 \mathrm{~cm}$ in that of area $\mathrm{B}$ );

Figure 8 shows the trend of the percentage of clay in the three soils at different depths, from which it is possible to deduce the greater resistance to vertical water flow of the clayey matrix in the area $\mathrm{C}$ profile.

Finally, as concerns chemical fertility parameters, all soil profiles showed an excellent content of organic matter, especially in the surface horizon, to which also corresponds a good content of total nitrogen (Tab. 3). The reserve of the exchange bases is generally high as is shown by the CEC which is almost always $>20$ me/100g. Among the other macroelements there is a low or very low content both of available phosphorus and exchangeable potassium, which does not appear to influence the floristic composition of the pasture.

\subsection{Hydrodynamic characteristics}

The differences in the hydrological behaviour of soils in areas B and C represented the starting point for further investigation into their water retention properties and mechanical consistency so as to identify the humidity limits to take into consideration in determining the best use of the soil for grazing.

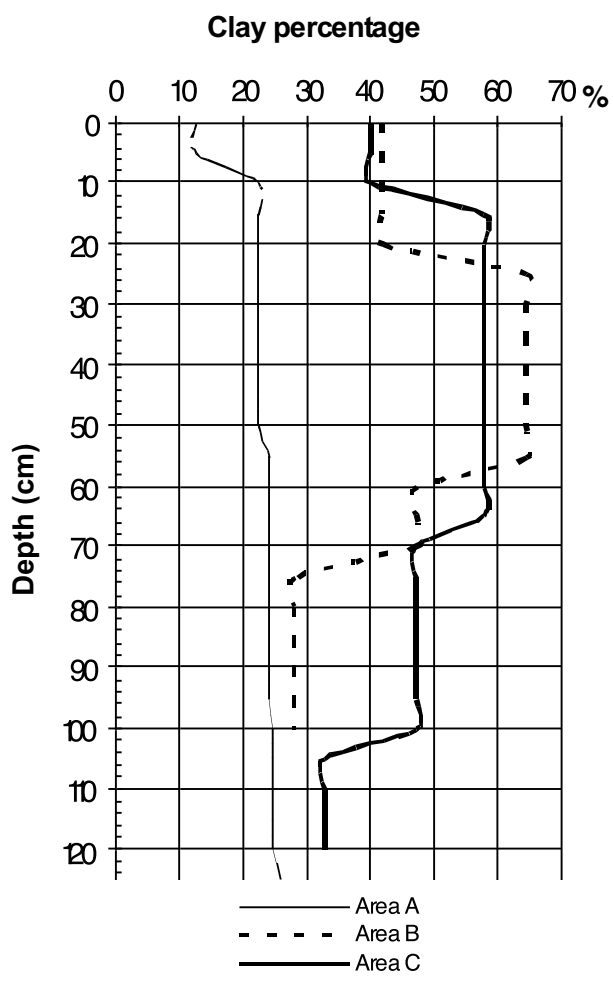

Figure 8. Variations in clay content at different depths in the three soil profiles. 
Salis L., Puddu R., Fanni S., Vargiu M.

Table 4. Water content and indices of soil consistency in areas B and C in relation to date of determination.

\begin{tabular}{llcccrr}
\hline Area & Parameters & 8 April & 4 May & 23 May & 9 June & 22 June \\
\hline B & Wc (\%) & 52.26 & 40.62 & 40.57 & 28.96 & 34.56 \\
& Ic & 0.69 & 0.98 & 0.99 & 1.28 & 1.14 \\
& & plastic & solid-plastic & solid-plastic & solid & solid \\
\hline C & Wc (\%) & 57.79 & 49.84 & 44.78 & 32.69 & 30.00 \\
& Ic & 0.45 & 0.63 & 0.75 & 1.03 & 1.09 \\
& & soft plastic & plastic & solid-plastic & solid & solid \\
\hline
\end{tabular}

Area B
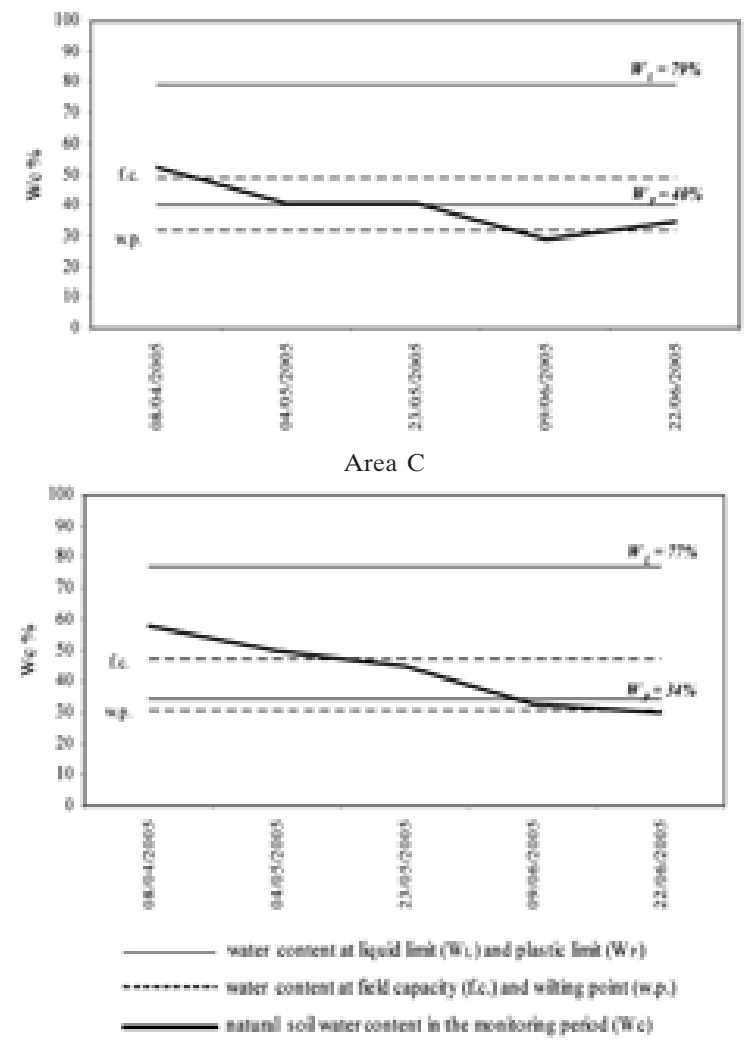

Figure 9. Natural water content measured in the spring of 2005 in areas B and C and its relationship to water content at field capacity, at wilting point and at liquid and plastic limits.

In areas $\mathrm{B}$ and $\mathrm{C}$ the soil moisture content values in the natural state $(\mathrm{Wc})$ compared to water stress values at field capacity (f.c.) and wilting point (w.p.), represented in Figure 9, underscored the fact that in spring the excess of water (Wc $>$ f.c.) in area $\mathrm{C}$ lasted for approximately 30 days longer than in area $\mathrm{B}$. There was also a difference in the beginning of the dry period (Wc < w.p.) which in area B began some 20 days before area $\mathrm{C}$. This fact, besides having a clear influence on vegetational characteristics, also imposes important limits on the management of the two types of soil as concerns the duration of the period during which they can support the passage of animals.

Thus to have an indication of the consistency of these soils with variation in water content and to distinguish their capacity for deformation under the compression done by the animals, we calculated the relative consistency index (Ic) for the surface horizons derived from Atterberg's limits during the period in which soil moisture was monitored (Tab. 4).

Determining the consistency index, we estimated the water content values above which the passage of animals may have a deteriorating effect on the physical and structural characteristics of the two soils. We calculated that the water content limit condition for the passage of animals is given by values around $45 \%$ for area $\mathrm{C}$ soil and about $50 \%$ in that of area $\mathrm{B}$, relative to a soil consistency between plastic and solidplastic, with an Ic $\geq 0.75$ (Casadio and Elmi, 1995). For these consistency classes a resistance to compression of $0.5 \div 1 \mathrm{~kg} \mathrm{~cm}^{-2}$ (Colombo, 1984) is estimated; this range is considered compatible with values of unit pressure applied by each sheep, estimated in $0.50 \mathrm{~kg} \mathrm{~cm}^{-2}$ (Pulina et al., 1994).

From table 4, in which we see the values of Wc and Ic in the two soils in the period monitored, we can deduce that the area B soils reached the condition for the passage of animals at least 20 days before those of area $\mathrm{C}$, which bears witness to an appreciable spatial variability in soil characteristics even in small areas and the consequent need to base proper soil use for grazing on objective determination of such characteristics through detailed studies.

The work presented herein, although not exhaustive of the complex dynamics involved in soil deterioration caused by overgrazing, may 
provide useful information in the planning of further experimental tests with a view to verifying variations in soil structural stability under different stocking rate and moisture conditions.

\section{Conclusions}

The study performed confirms the high level of biodiversity to be found in Sardinia's grazing lands. The pasture examined, despite its limited extension, presents three areas that are clearly different as concerns vegetational, humidity and pedological characteristics. The phyto pastoral facies relating to the three areas vary especially as concerns the differences in frequency of the different vegetable species. The factors that lead to such balances are to be found in the variations in the textures and depths of the impermeable horizons which, especially in the more depressed areas, lead to different soil hydrodynamic conditions and thus to the presence and different duration of waterlogging on the surface. Despite this, the three grazing areas all possess good grazing value (above 35 in all cases), owing to the presence of species having high forage value.

The limit of the grazing land examined consists of its partial use by animals which adapt poorly to the long periods of waterlogging that are frequent in areas $\mathrm{B}$ and $\mathrm{C}$; furthermore, the special nature of the clayey matrix, of the expandable clay, implies different responses to the mechanical stresses produced by the passage of animals, thus calling for a plan for diversified grazing to reduce the risk of deterioration of the soil structure. A general indication of the water content values at which soil structure can be preserved from the action of treading by animals was given by an analysis of the indices of soil consistency with the time variation of its water content. In the specific case it was estimated that on the grazing land investigated the highest threshold for water content should be approximately $45 \%$, corresponding to the critical value for the most disadvantaged area (area C).

An extension of the grazing period in these areas can be obtained through creation of a drainage system allowing at least partial removal of excess water, thus limiting the duration of logging. The solutions that emerge suggest ways to improve the floristic characteris- tics of the pasture, with consequent agronomic upgrading of the area and at the same time preservation of the soil from possible degradation caused by improper use by animals.

\section{Acknowledgements}

The authors thank Dr. Vincenzo Satta for his assistance in the vegetational studies, Prof. A. Aru and Drs E. Spanu, Daniele Manca and M. Sitzia for their precious suggestions.

\section{References}

Arrigoni P.V. 1968. Fitoclimatologia della Sardegna. Webbia, 23:1-100.

Arrigoni P.V. 2006. Flora dell'Isola di Sardegna. Carlo Delfino editore, Sassari.

Aru A., Baldaccini P., Vacca A. 1991. Nota illustrativa alla carta dei suoli della Sardegna, RAS, 66-67.

Aru A., Baldaccini P., Dessena M.A., Fantola F., Lai M.R., Loddo S., Madrau S., Puddu R., Serra G., Tomasi D., Vacca A., Vacca S. 1998. La qualità del suolo per un ambiente sostenibile: il caso Sardegna. Bollettino Società Italiana Scienza del Suolo, anno XLVII, 3:311-334.

Camarda I. 1987. Un approccio alla conoscenza dei pascoli naturali della Sardegna. Atti del Convegno Ersat, Valorizzazione delle risorse produttive dei pascoli e salvaguardia dell'ambiente in Sardegna, 30-59.

Carmignani L. 2001. Carta Geologica della Sardegna, scala 1:200.000.

Casadio M., Elmi C. 1995. Il manuale del Geologo. Pitagora editrice, Bologna.

Colombo P. 1984. Elementi di geotecnica. Zanichelli, Bologna.

Daget P., Poissonet Y. 1969. Analyse phytologique des prairies. Application agronomiques. CNRS, CEPR Montpellier, Doc 48-67.

FAO, 1977. Guidelines for soil profile description.

Guckert A., Bonischot R. 1984. Influence of the pedoclimatic factors on the floristic composition of grasslands. In: Proceedings of the $10^{\text {th }}$ general Meeting of the EGF, "The impact of climate on grass production and quality", 156-165.

ISTAT, 2005. Dati congiunturali.

Pagliai M. (eds.) 2001. Metodi di analisi fisica del suolo. Collana di metodi analitici per l'agricoltura. Edizione Franco Angeli, Milano.

Pignatti S. 1982. Flora d'Italia. Edagricole, Bologna.

Pulina G., Zanda A., Enne G. 1994. The impact of animal husbandry on the degradation of the soil. In: Land Use and soil degradation. MEDALUS in Sardinia. Proceedings of the conference held in Sassari, Italy, 25 May, 231-238. 
Roggero P.P., Bagella S., Farina R. 2002. Un archivio dati di Indici specifici per la valutazione integrata del valore pastorale. Rivista di Agronomia, 36:149-156.

Salis L., Vargiu M., Spanu E., Loche F. 2005. Overgrazing influence on the presence of legumes in a natural pasture of Sardinia. In: XX International Grassland Congress: Offred papers, 635.

USDA Soil Survey Staff 2006. Keys to Soil Taxonomy. Tenth Edition. United States Department of Agricolture, Washington, D.C.
Vacca A., Loddo S., Serra G., Aru A. 2003. Soil degradation in Sardinia (Italy): main factors and processes. In: P. Zdruli, P. Steduto, S. Kapur (eds.): $7^{\text {th }}$ International Meeting on Soils with Mediterranean Type of Climate (Selected Papers), Options Méditerranéennes, Series: Mediterranean Seminars, Vol. A54, Valenzano (BA), Italy.

Violante P. (eds.) 2000. Metodi di analisi chimica del suolo. Collana di metodi analitici per l'agricoltura. Edizione Franco Angeli, Milano. 